\title{
Expression Pattern of Early Growth Response Gene 1 during Olive Flounder (Paralichthys olivaceus) Embryonic Development
}

\author{
Hyun Yang, ${ }^{\dagger}$ Jeong-Ho Lee, Jae Koo Noh, Hyun Chul Kim, Choul-Ji Park, \\ Jong-Won Park and Kyung-Kil Kim \\ Genetics and Breeding Research Center, NFRDI, Geoje 656-842, Korea
}

\begin{abstract}
The early growth response protein 1 (Egr-1) is a widely reported zinc finger protein and a well known transcription factor encoded by the Egr-1 gene, which plays key roles in many aspects of vertebrate embryogenesis and in adult vertebrates. The Egr-1 expression is important in the formation of the gill vascular system in flounders, which develops during the post-hatching phase and is essential for survival during the juvenile period. However, the complete details of Egr-1 expression during embryo development in olive flounder are not available. We assessed the expression patterns of Egr-1 during the early development of olive flounders by using reverse transcription polymerase chain reaction (RT-PCR) analysis. Microscopic observations showed that gill filament formation corresponded with the Egr-1 expression. Thus, we showed that Egr-1 plays a vital role in angiogenesis in the gill filaments during embryogenesis. Further, Egr-1 expression was found to be strong at 5 days after hatching (DAH), in the development of the gill vascular system, and this strong expression level was maintained throughout all the development stages. Our findings have important implications with respect to the biological role of Egr-1 and evolution of the first respiratory blood vessels in the gills of olive flounder. Further studies are required to elucidate the Egr-1-mediated stress response and to decipher the functional role of Egr-1 in developmental stages.
\end{abstract}

Key words : Egr-1 (Early growth response protein 1), Gill vessels system, Embryogenesis, Gene expression, Gill filament, Olive flounder

\section{INTRODUCTION}

The early growth response (Egr) 1 is a member of the immediate-early gene family that includes Cys2-His2 class of zinc finger proteins. This gene encodes a 533 amino acid, $57 \mathrm{kDa}$ protein containing three putative DNA- binding zinc finger elements (Sukhatme et al., 1987; McMahon et al., 1990). Early growth response protein 1 (Egr-1), a zinc finger transcription factor (TF) is, also known as KROX24, NGFI-A, ZIF-268, and TIS8 (Moratalla et al., 1992;
Humblot et al., 1997; Topilko et al., 1997; Knapska \& Kaczmarek, 2004). This protein activates transcription via a high-affinity regulatory element GCG(G/T)GGGCG in a zinc-dependent manner (Decker et al., 1998; Tremblay \& Drouin, 1999).

Studies have shown Egr-1 mRNA during frog embryogenesis for the development of the bone and muscle, as well as several other mesodermal structures, including tooth mesenchyme and hair follicles (Mcmahon et al., 1990; Nentwich et al., 2009). In adult mice, the maximum

\footnotetext{
Manuscript received 23 October 2014, Received in revised form 17 November 2014, Accepted 19 November 2014

${ }^{\dagger}$ Corresponding Author : Jeong-Ho Lee, Genetics and Breeding Research Center, NFRDI, Geoje 656-842, Korea. Tel : +82-55-639-5811, Fax : +82-55639-5809, E-mail : jhlee7124@korea.kr

This is an Open Access article distributed under the terms of the Creative Commons Attribution Non-Commercial License (http:// creativecommons.org/licenses/by-nc/3.0) which permits unrestricted non-commercial use, distribution, and reproduction in any medium, provided the original work is properly cited.
} 
expression levels of Egr-1 mRNA are restricted to the heart, brain, and lung, and the minimum expression levels, to the spleen and kidney (Milbrandt, 1987; Christy et al., 1988; Lemaire et al., 1988; Langmann, 2007). In zebra fish, several tissues express Egr-1, including the hypothalamus, pharynx, retina, and optic vesicle during embryogenesis (Close et al., 2002; Langmann, 2007).

Initially, Egr-1 was considered to be an immediate early gene that rapidly responded to different growth stimuli and involved in cell proliferation, differentiation, and development, because it was induced in quiescent fibroblasts exposed to serum growth factors (Nguyen et al., 1993; Svaren et al., 1996). Egr-1 binds to GC-rich, cis-acting promoter elements (Khachigian et al., 1997; FernandezAlvarez et al., 2008), and controls the expression of a wide variety of genes relevant to pathogenesis (Hasan et al., 2003; Blaschke et al., 2004), including growth factors, cytokines, receptors, and proteases, many of which are involved in angiogenesis (Lucerna et al., 2003). For example, the expression of Egr-1 has been shown to be activated by acidic fibroblast growth factor (aFGF), basic fibroblast growth factor (bFGF), vascular endothelial growth factor (VEGF), and shear stress (Silverman \& Collins, 1999; Urakawa et al., 2006).

Egr-1 mediates by angiogenesis through the activation of the vascular endothelial growth factor (VEGF) gene (Mechtcheriakova et al., 1999; Liu et al., 2000). Thus, angiogenesis that occurs during the development stage leads to the formation of the gill vascular system. This is essential for gas exchange and respiratory metabolism during fish embryogenesis. The gill vascular system of teleosts, elasmobranchs, and dipnoans has been researched extensively over the last a few years (Kimmel et al., 1995). However, the role of Egr-1 expression in gill vascular system formation during embryogenesis is still unclear.

Here, we investigated the role of the growth factor inducible Egr-1 in gill vascular formation during embryo- genesis of olive flounders. We also assessed the accompanied changes in the expression patterns of Egr-1 from fertilization to post-hatching period. Additionally, we examined the expression patterns of Egr-1 in several tissues of the olive flounder.

\section{MATERIALS AND METHODS}

\section{Fish breeding and RNA purification}

All experimental fish were raised at Genetics and Breeding Research Center, National Fisheries Research and Development Institute (NFRDI) and maintained in 10 tons flow through tank at $20 \pm 1^{\circ} \mathrm{C}$ under a natural photoperiod. Different stages of embryo $(0.92 \pm 0.02 \mathrm{~mm})$, larvae $(2.49 \pm$ $0.34 \mathrm{~mm})$ and juvenile $(3.5 \pm 0.45 \mathrm{~mm})$ development were described from fish kept at $20^{\circ} \mathrm{C}$ in the tank. Several tissues of 2 years ( $38 \mathrm{~cm} \pm \mathrm{SEM}$ ) old were used to in olive flounder. The samples of 10 fish were randomly collected and frozen in $70^{\circ} \mathrm{C}$ deep freezer until isolation of total RNA. Pooled several tissues were homogenized for $20 \mathrm{sec}$ with Trizol reagent (Invitrogen, Carlsbad, CA, USA).

\section{Microscopic analysis}

Larvae were examined as previously described, fixed at room temperature, in 2.5\% glutaraldehyde (Polysciences, Inc., Warrington, PA) in $0.1 \mathrm{M}$ sodium cacodylate- $\mathrm{HCl}$ buffer, $\mathrm{pH} 7.3$, for $10 \mathrm{~min}$, and post fixed in $1 \%$ paraformaldehyde (Sigma-Aldrich, CA, USA) in the same buffer, for $20 \mathrm{~min}$ with $1 \%$ uranyl acetate for $1 \mathrm{~h}$ and ethanol dehydration. The samples were examined under a stereo microscope (ZEISS CL1500 ECO Jena, Germany) imaging system at $\times 400$ magnification of development was determined. The 5 days after hatching stage of gill vessels system development were illustrated using a Power point (Microsoft, WAS., USA)

3. Traditional reverse transcription-polymerase chain reaction ( $\mathrm{RT}$-PCR) 
Total RNA was extracted using the Trizol Reagent (Invitrogen, Carlsbad, CA, USA) according to the manufacturer's protocol. DNase-I (Sigma-Aldrich, CA, USA) was treated for removing genomic DNA contamination from RNA for $30 \mathrm{~min}$ at $37^{\circ} \mathrm{C}$. The RNA samples were extracted with phenol/chloroform to inactivate the DNase I. RNA concentration was measured with spectrophotometer (Gene-Quant, Pharmacia Biotech), quality of RNA was checked by gel electrophoresis (1\% agarose gel) and stored at $-80^{\circ} \mathrm{C}$ until further use. RNA (100 ng) from each sample was transcribed to cDNA using RT-\&GO Mastermix (Qbiogene, Inc., Virgi., USA). The amplification was performed with AmpliTag Gold DNA Polymerase (Applied Biosystems., CA, USA) and Veriti Thermal Cycler (Applied Biosystems., CA, USA) using the following parameters: denaturation at $95^{\circ} \mathrm{C}$ for 10 minutes and 35 cycles of reactions of denaturation at $98^{\circ} \mathrm{C}$ for $10 \mathrm{~s}$, annealing at $58^{\circ} \mathrm{C}$ for $30 \mathrm{~s}$, and elongation at $72^{\circ} \mathrm{C}$ for $45 \mathrm{~s}$. An aliquot of each PCR product was subjected to $1.5 \%(\mathrm{w} / \mathrm{v})$ agarose gel electrophoresis and visualized by staining with Red Safe (Intron, Seoul, Korea). A search of the National Center for Biotechnology Information (NCBI) data base revealed a partial sequence similar to that of Egr-1 (KC442103.1). The 5' forward and 3' reverse-complement PCR primers for amplification of each gene were as follows: Egr-1 (forward primer: 5'-CCTGCCTA CCCAAATAGCAA-3' and reverse primer 5'-GTGGATGCGAATATGTCGTG3'), $\beta$-Actin (forward primer: 5'-TGATGAAGCCCAGA GCAAGA-3' and reverse primer 5'-CTCCATGTCATCC CAGTTGG-3'). Relative amount of each messenger RNA was quantified by dividing by density of housekeeping gene (Gene bank, HQ 386788.1).

\section{Real-time-PCR analysis}

To evaluate arrestin mRNA levels, these primers were specifically designed to detect and quantify cDNA sequences without detecting genomic DNA. The Fast-Start
DNA Master SYBR Green I (Roche Ltd., SWISS) was used as fluorescent reporter dye to detect amplification products in 7500 Fast Real Time PCR System (Applied Biosystems Inc. Carlsbad, CA, USA) using the following cycling conditions: denaturation at $95^{\circ} \mathrm{C}$ for $10 \mathrm{~min}$ and 40 cycles of reactions of denaturation at $95^{\circ} \mathrm{C}$ for $10 \mathrm{~s}$, annealing at $58^{\circ} \mathrm{C}$ for $30 \mathrm{~s}$, and elongation at $72^{\circ} \mathrm{C}$ for $30 \mathrm{~s}$. Each sample was tested in triplicate to ensure statistical significance. The PCR efficiency (E\%) of gene was derived from perforin (96.2\%) and $\beta$-Actin (95.4\%) respectively. The relative quantification of arrestin gene expression was performed using the comparative $C_{\mathrm{t}}$ method. The $C_{\mathrm{t}}$ value is defined as the point where a statistically significant increase in the fluorescence has occurred. The number of PCR cycles $\left(C_{\mathrm{t}}\right)$ required for the ROX intensities to exceed a threshold just above background was calculated for the test and reference reactions. In all experiments, $\beta$-Actin was used as the endogenous control. Results were analyzed in a relative quantitation study with the vehicle treated.

\section{Statistical analysis}

Data were analyzed using Sigma plot for Windows (Jandel Scientific, San Rafael, CA, USA). For unpaired matched comparative analysis of multiple groups, an analysis of variance (ANOVA) was performed. Data that did not meet normality assumptions were subjected to one way ANOVA on ranks, and then pair wise comparisons were made using the Student-Newman-Keuls (SNK) method.

\section{RESULTS}

\section{Formation of the gill vessels system in embryo- genesis}

Microscopic analysis of gill vessels formation was performed at the end of the embryonic stage and at the beginning of larval development of the flatfish. The period of embryogenesis in the olive flounder is about 5 days 
after hatching (DAH) at $20^{\circ} \mathrm{C}$. We first observed the lateral side of the live olive flounder larvae 5 DAH by using a dissecting stereomicroscope. At this stage, the eye, heart, gill filament, auditory capsule, hyoid arch vessels, and gill arch vessels were visible, which are all generated from the back of the eyes (Fig. 1A). At this stage, the blood vessels of the gill, hyoid, and gill arches of the calculate system function as provisory respiration organs (Fig. 1A). To
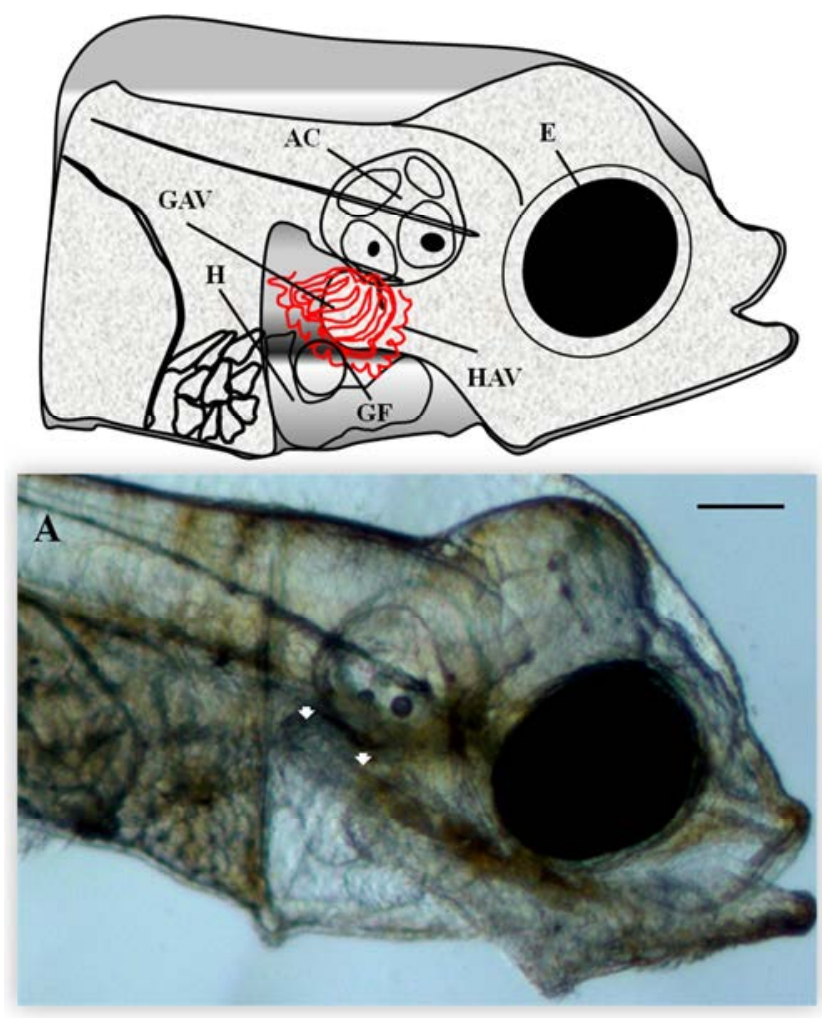

Fig.1. Gill vessels system form during embryogenesis in Olive flounder. The experiment was fertilized eggs of olive flounder from the tank, oxygen supply and maintains a temperature of $20^{\circ} \mathrm{C}$. Schematic lateral view of the head and gill vessels system (white arrow) of a flat fish with key features labeled. (A) Photograph was shown during after hatching for 5 days, Magnification: $\times 400$. The following structures can be identified in development olive flounder larvae under dissecting stereomicroscopes $(\mathrm{E}$, eye; $\mathrm{H}$, heart; AC, auditory capsule; GF, gill filament; GAV, gill arch vessels; HAV, hyoid arch vessel). Scale bar, $300 \mu \mathrm{m}$. determine the origin of the gill vessels system during embryonic development in the olive flounder, larvae 3.5 $\mathrm{mm}$ in length were observed. Within $5 \mathrm{DAH}$, most of the gill filaments already contained capillary vessels, and these were present in almost all gill filaments by 7 DAH. Just after hatching, rudiments of the gill filaments were formed on the gill arches. Within $5 \mathrm{DAH}$, the gill filaments had begun to branch and contained gill capillaries. A gill slit was formed posterior to the hyoid arch and between each branchial arch, forming five slits in all. The rudiments of the gill filaments develop late in the hatching stage as buds along the posterior walls of the branchial arches facing the slits. The gill vessels system in the 5-DAH larvae consisted of gill arch vessels, hyoid arch vessels, and gill filaments. Figure 1A shows the gill vessels under the auditory capsule at 5 DAH and the gill filaments budding laterally to connect with the gill arch vessels, which function as the circulation system.

\section{Expression analysis of the egr-1 gene during} development of the gill vessels system and other tissues

Egr-1 expression was measured during olive flounder embryogenesis and in several tissues by using traditional reverse transcription-polymerase chain reaction (RT-PCR). Egr-1 gene induction was not observed during the first stages of development from the fertilization stage to the gastrula stage. Egr-1 expression was first detected at the beginning of the neurula stage, and then increased continually until the larval period, and strong expression was observed at 5 DAH (Fig. 2A). High egr-1 expression was observed in the spleen and gills, and lower expression levels were observed in the fins, eyes, and kidneys (Fig 3A). Egr-1 expression in olive flounder during embryogenesis and in various organs from adults was also examined using realtime time PCR (Fig. 2B, 3B). Similar egr-1 expression levels were observed from the neurula period to $5 \mathrm{DAH}$. In 
A

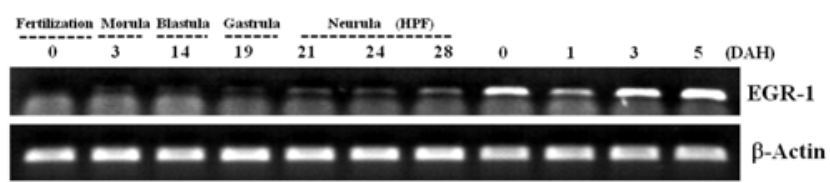

B

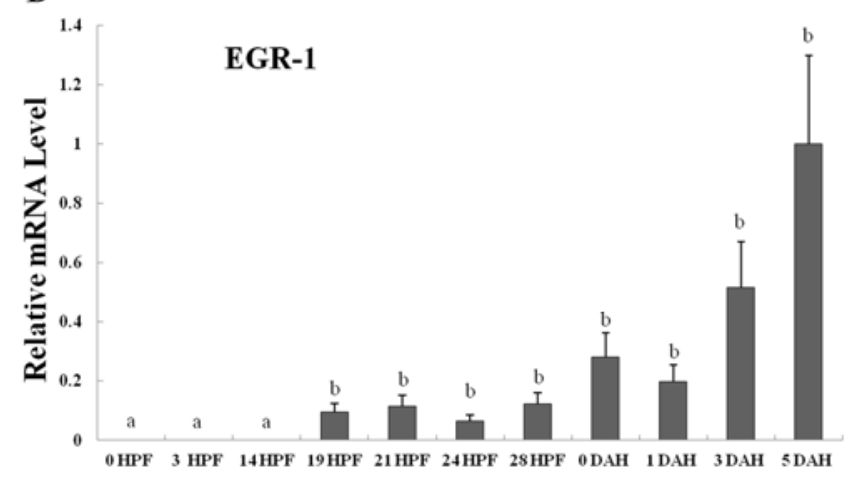

Fig.2. EGR-1 gene induces during embryogenesis in Olive flounder. (A) The experiment was flounder fertilized eggs from the tank, oxygen supply and maintain a temperature of $20^{\circ} \mathrm{C}$. Embryo and larva were harvested during hours post fertilization (HPF) and days after hatching (DAH) for the indicated periods. The RNA extracted and perforin was analyzed by RT-PCR method. (B) The mRNA expression of EGR-1 was analyzed by real-time PCR. Different letters over each bar with the standard deviation represent significant differences one group according to unpaired matched comparisons $(p<0.05)$.

adults, egr-1 mRNA was expressed at similar levels in the spleen and gills, but lower expression was observed in the fins, eyes, and kidneys (Fig. 2B, 3B). These results show that egr-1 is more strongly expressed during development of the gill vessels system, which suggests that it plays a role in gill vessels formation during embryogenesis.

\section{DISCUSSION}

The change from embryogenesis to the larval stage of growth in fish is accompanied by regulated substitution of the provisory respiratory organs with the definitive organs (Kimmel et al., 1995). Previous studies have established that the gill vessels system is fully formed and egr-1
$\mathbf{A}$

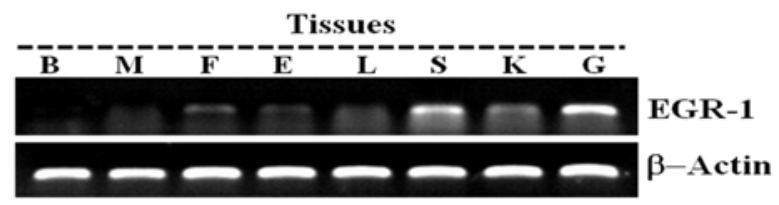

B

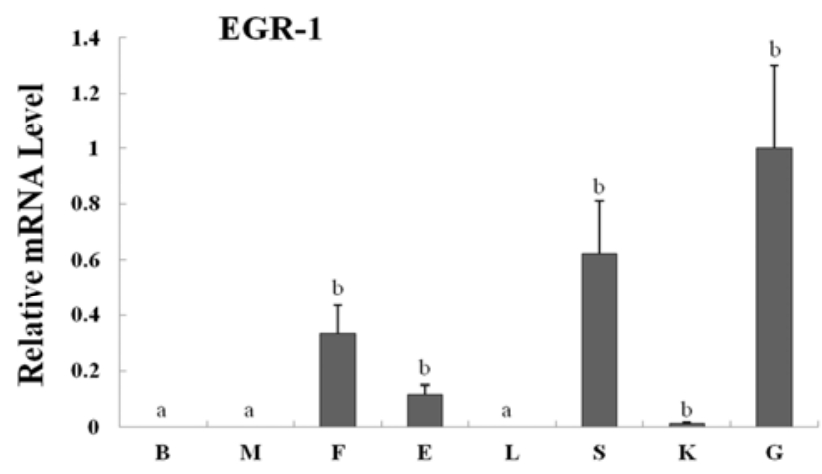

Fig.3. EGR-1 gene induces in the several tissues from Olive flounder. Experiments are examined with various periods of adult fish. (A) EGR-1 gene expression from the segmental tissue (B: brain, $\mathrm{M}$ : muscle, F: fin, E: eye, L: liver, S: spleen, K: kidney, $\mathrm{G}$ : gill) for the olive flounder at 2 years of age were analyzed using RT-PCR. (B) The mRNA expression of perforin was analyzed by real-time PCR. Different letters over each bar with the standard deviation represent significant differences one group according to unpaired matched comparisons $(p<0.05)$.

expression is detected within days after hatching in zebra fish (Oxtoby \& Jowett, 1993; Close et al., 2002). However, the formation of the gill vessels system in relation to expression of the egr-1 gene has not been described previously. Guided by the position of the mature gill vessels system, we examined the cellular structures medial to the blood cartilages of the gill vessels system at various time points during development to define the stages of vascular system formation. At $5 \mathrm{DAH}$, a gill filament was observed lateral to the head (Fig. 1A). The development of the formation of the initial vascular system expressed in embryogenesis is also preserved at later developmental stages. For example, stickleback larvae have gills with various filaments that already begin to branch and contain capillary vessels by the beginning of the transition to the 
opened mouth stage (Swarup, 1958; Shadrin \& Ozerniuk, 2002). By contrast, in the zebrafish, at the initial stages of metamorphosis (about $18 \mathrm{DAH}$ ), the larvae already have an almost complete definitive gill system. In olive flounder, formation of the gill vessels system is an essential component of the development of respiratory metabolism and is dependent on the expression of VEGF during embryogenesis (Scehnet et al., 2007; Trindade et al., 2008). VEGF/ VEGFR signaling pathways are essential for vascular and hematopoietic cell development (Giles, 2001). Gain-offunction studies have shown that VEGF expression in endothelial cells is mediated by Egr-1 (Liu et al., 2000). Our data showed that Egr-1 mRNA was expressed and detectable until 5 DAH in olive flounder (Fig. 2A, B). Systemically administered VEGF led to increased Egr-1 protein levels in the micro-vascular endothelium of the liver and heart, and administration of EGF resulted in Egr1 induction in the micro-vascular endothelial cells of the skeletal muscle (Gerritsen, 1987; Silverman \& Collins, 1999). Recently, Egr-1 protein was shown to be expressed in a variety of cells in adult mice, including hepatocytes, neuronal cells, cardiomyocytes, and endothelial and vascular smooth muscle cells (Cohen et al., 1996). Inducible Egr-1 expression may coordinate the expression of multiple target genes involved in cell movement and replication in blood vessel walls (Ayadi et al., 2001). The vascular system has a mesodermal origin, and there is evidence that Egr-1 plays an important role in vascular biology (Lejard et al.; Mechtcheriakova et al., 2001). Similar to previous reports, we also found that egr-1 is expressed at relatively high levels in the gill vessels system and lymphoid organs in the tissues of adult flounder (Fig. 3A, B). Gill vessels system formation was observed in the larval stages, and the Egr-1 gene was significantly expressed in these stages, suggesting that Egr-1 may play a crucial role in the larval respiration vessels system.

In summary, expression analysis of Egr-1 during gill vessels formation might provide information that could be useful in understanding the initial respiration responses and growth of olive flounder larvae. Further functional studies of this gene will help to elucidate the molecular regulatory mechanisms and the stress response involved in gill vessels formation in olive flounder.

\section{ACKNOWLEDGEMENTS}

This work was supported by a grant from the National Fisheries Research and Development Institute (NFRDI), contribution number RP-2014-BT-54.

\section{REFERENCES}

Ayadi A, Zheng H, Sobieszczuk P, Buchwalter G, Moerman P, Alitalo K, Wasylyk B (2001) Net-targeted mutant mice develop a vascular phenotype and up-regulate egr-1. Embo J 20:5139-5152.

Blaschke F, Bruemmer D, Law RE (2004) Egr-1 is a major vascular pathogenic transcription factor in atherosclerosis and restenosis. Rev Endocr Metab Disord 5:249-254.

Christy B A, Lau LF, Nathans D (1988) A gene activated in mouse $3 \mathrm{~T} 3$ cells by serum growth factors encodes a protein with "zinc finger" sequences. Proc Natl Acad Sci USA 85:7857-7861.

Close R, Toro S, Martial JA, Muller M (2002) Expression of the zinc finger Egr1 gene during zebrafish embryonic development. Mech Dev 118:269-272.

Cohen DM, Gullans SR, Chin WW (1996) Urea inducibility of egr-1 in murine inner medullary collecting duct cells is mediated by the serum response element and adjacent Ets motifs. J Biol Chem 271:12903-12908.

Decker EL, Skerka C, Zipfel PF (1998) The early growth response protein (EGR-1) regulates interleukin-2 transcription by synergistic interaction with the nuclear factor of activated T cells. J Biol Chem 273:26923- 
Expression Pattern of Early Growth Response Gene 1 during Olive flounder (Paralichthys olivaceus) Embryonic Development

26930.

Fernandez-Alvarez A, Tur G, Lopez-Rodas G, Casado M (2008) Reciprocal regulation of the human sterol regulatory element binding protein (SREBP)-1a promoter by $\mathrm{Sp} 1$ and EGR-1 transcription factors. FEBS Lett 582:177-184

Gerritsen ME (1987) Functional heterogeneity of vascular endothelial cells. Biochem Pharmacol 36:2701-2711.

Giles FJ (2001) The vascular endothelial growth factor (VEGF) signaling pathway: a therapeutic target in patients with hematologic malignancies. Oncologist 6 Suppl 5:32-39.

Hasan RN, Phukan S, Harada S (2003) Differential regulation of early growth response gene-1 expression by insulin and glucose in vascular endothelial cells. Arterioscler Thromb Vasc Biol 23:988-993.

Humblot N, Esteve L, Burgun C, Aunis D, Zwiller J (1997) 5-Hydroxytryptamine induces TIS8/egr-1 and c-fos expression in PC12 cells. Involvement of tyrosine protein phosphorylation. Eur J Neurosci 9: 84-92.

Khachigian LM, Anderson KR, Halnon NJ, Gimbrone MA Jr, Resnick N, Collins T (1997) Egr-1 is activated in endothelial cells exposed to fluid shear stress and interacts with a novel shear-stress-response element in the PDGF A-chain promoter. Arterioscler Thromb Vasc Biol 17:2280-2286.

Kimmel CB, Ballard WW, Kimmel SR, Ullmann B, Schilling TF (1995) Stages of embryonic development of the zebrafish. Dev Dyn 203:253-310.

Knapska E, Kaczmarek L (2004) A gene for neuronal plasticity in the mammalian brain: Zif268/Egr-1/NGFIA/Krox-24/TIS8/ZENK Prog Neurobiol 74:183-211.

Langmann T (2007) Microglia activation in retinal degeneration. J Leukoc Biol 81:1345-1351.

Lejard V, Blais F, Guerquin MJ, Bonnet A, Bonnin MA, Havis E, Malbouyres M, Bidaud CB, Maro G, GilardiHebenstreit P, Rossert J, Ruggiero F, Duprez D (1998) EGR1 and EGR2 involvement in vertebrate tendon differentiation. J Biol Chem 286:5855-5867.

Lemaire P, Revelant O, Bravo R, Charnay P (1988) Two mouse genes encoding potential transcription factors with identical DNA-binding domains are activated by growth factors in cultured cells. Proc Natl Acad Sci USA 85:4691-4695.

Liu L, Tsai JC, Aird WC (2000) Egr-1 gene is induced by the systemic administration of the vascular endothelial growth factor and the epidermal growth factor. Blood 96:1772-1781.

Lucerna M, Mechtcheriakova D, Kadl A, Schabbauer G, Schafer R, Gruber F, Koshelnick Y, Muller HD, Issbrucker K, Clauss M, Binder BR, Hofer E (2003) NAB2, a corepressor of EGR-1, inhibits vascular endothelial growth factor-mediated gene induction and angiogenic responses of endothelial cells. J Biol Chem 278: 11433-11440.

McMahon AP, Champion JE, McMahon JA, Sukhatme VP (1990) Developmental expression of the putative transcription factor Egr-1 suggests that Egr-1 and c-fos are coregulated in some tissues. Development 108:281-287.

Mechtcheriakova D, Schabbauer G, Lucerna M, Clauss M, De Martin R, Binder BR, Hofer E (2001) Specificity, diversity, and convergence in VEGF and TNF-alpha signaling events leading to tissue factor up-regulation via EGR-1 in endothelial cells. Faseb J 15:230-242.

Mechtcheriakova D, Wlachos A, Holzmuller H, Binder B R, Hofer E (1999) Vascular endothelial cell growth factor-induced tissue factor expression in endothelial cells is mediated by EGR-1. Blood 93:3811-3823.

Milbrandt J (1987) A nerve growth factor-induced gene encodes a possible transcriptional regulatory factor. Science 238:797-799.

Moratalla R, Robertson HA, Graybiel AM (1992) Dynamic regulation of NGFI-A (zif268, egr1) gene expression in the striatum. J Neurosci 12:2609-2622.

Nentwich O, Dingwell K S, Nordheim A, Smith JC (2009) 
Downstream of FGF during mesoderm formation in Xenopus: the roles of Elk-1 and Egr-1. Dev Biol 336: 313-326.

Nguyen HQ, Hoffman-Liebermann B, Liebermann DA (1993) The zinc finger transcription factor Egr-1 is essential for and restricts differentiation along the macrophage lineage. Cell 72:197-209.

Oxtoby E, Jowett T (1993) Cloning of the zebrafish krox20 gene (krx-20) and its expression during hindbrain development. Nucleic Acids Res 21:1087-1095.

Scehnet JS, Jiang W, Kumar SR, Krasnoperov V, Trindade A, Benedito R, Djokovic D, Borges C, Ley EJ, Duarte A, Gill PS (2007) Inhibition of Dll4-mediated signaling induces proliferation of immature vessels and results in poor tissue perfusion. Blood 109:4753-4760.

Shadrin AM, Ozerniuk ND (2002) [Development of the gill system in early ontogenesis of Danio and nine spike stickleback]. Ontogenez 33:118-123.

Silverman ES, Collins T (1999) Pathways of Egr-1-mediated gene transcription in vascular biology. Am J Pathol 154:665-670.

Sukhatme VP, Kartha S, Toback FG, Taub R, Hoover RG, Tsai-Morris CH (1987) A novel early growth response gene rapidly induced by fibroblast, epithelial cell and lymphocyte mitogens. Oncogene Res 1:343-355.

Svaren J, Sevetson BR, Apel E, Zimonjic DB, Popescu N
C, Milbrandt J (1996) NAB2, a corepressor of NGFI-A (Egr-1) and Krox20, is induced by proliferative and differentiative stimuli. Mol Cell Biol 16:3545-3553.

Swarup H (1958) Stages in the development of the stickleback Gasterosteus aculeatus (L.). J Embryol Exp Morphol 6:373-383.

Topilko P, Levi G, Merlo G, Mantero S, Desmarquet C, Mancardi G, Charnay P (1997) Differential regulation of the zinc finger genes Krox-20 and Krox-24 (Egr-1) suggests antagonistic roles in Schwann cells. J Neurosci Res 50:702-712.

Tremblay JJ, Drouin J (1999) Egr-1 is a downstream effector of GnRH and synergizes by direct interaction with Ptx 1 and SF-1 to enhance luteinizing hormone beta gene transcription. Mol Cell Biol 19:2567-2576.

Trindade A, Kumar SR, Scehnet JS, Lopes-da-Costa L, Becker J, Jiang W, Liu R, Gill PS, Duarte A (2008) Overexpression of delta-like 4 induces arterialization and attenuates vessel formation in developing mouse embryos. Blood 112:1720-1729.

Urakawa I, Yamazaki Y, Shimada T, Iijima K, Hasegawa H, Okawa K, Fujita T, Fukumoto S, Yamashita T (2006) Klotho converts canonical FGF receptor into a specific receptor for FGF23. Nature 444:770-774.

Zhang L, Cho J, Ptak D, Leung YF (2013) The role of egr1 in early zebrafish retinogenesis. PLoS One 8e:56108. 